\title{
NUTRITIONAL REGULATION OF GASTRIC SECRETION, DIGESTION AND EMPTYING
}

A. G. LOW

AFRC Institute of Grassland and Environmental Research, Church Lane, Shinfield, Reading, Berkshire RG2 9AQ

\section{CONTENTS}

INTRODUCTION . . . . . . . . . . . . . . . . 230

SECRETION . . . . . . . . . . . . . . . . . . 230

ACID SECRETION: PHYSIOLOGICAL ASPECTS . . . . . . . . . 230

ACID SECRETION: NUTRITIONAL ASPECTS . . . . . . . . . . . 231

The neonate. . . . . . . . . . . . . . . . . 231

Meal pH . . . . . . . . . . . . . . 231

Distension and meal size . . . . . . . . . . . . . . . . . 232

Particle size . . . . . . . . . . . . . . . . . . 232

Meal size and frequency . . . . . . . . . . . . . . . . 232

Dietary proteins, peptides and amino acids . . . . . . . . . . . . $\quad$. 232

Dietary carbohydrates . . . . . . . . . . . . . . 233

Dietary fats . . . . . . . . . . . . . . . 233

Beverages . . . . . . . . . . . . . . . . . . 233

Stimulatory effects of whole foods. . . . . . . . . . . . . . . . . . 234

BICARBONATE SECRETION . . . . . . . . . . . . . . . . . . . . 234

PEPSINOGEN SECRETION . . . . . . . . . . . . . . . 234

The neonate. . . . . . . . . . . . . . . . . . . 235

Growing pigs. . . . . . . . . . . . . . . . 235

MUCUS SECRETION . . . . . . . . . . . . . . . . . . . . 236

PROTEIN SYNTHESIS AND TURNOVER. . . . . . . . . . . . . 236

VOLUME OF SECRETION .

DIGESTION . . . . . . . . . . . . . . . . . . . . . . 237

PROTEINS. . . . . . . . . . . . . . . . . . 237

CARBOHY DRATES .

FAT . . . . . . . . . . . . . . . . . 237

MICROBIAL DIGESTION . . . . . . . . . . . . . . . . . . . 538

GASTRIC EMPTYING

PHYSIOLOGICAL ASPECTS .

MEASUREMENT $\quad$.

NUTRITIONAL ASPECTS.

Influence of meal volume . . . . . . . . . . . . . . . . . . . . . . 240

Particle size . . . . . . . . . . . . . . . . . 241

Viscosity . . . . . . . . . . . . . . . . . . . . . . . . 241 
Osmolarity

Acids

Lipids

Proteins and amino acids

Sugars

Starch

Non-starch polysaccharides

Energy content of meals

CONCLUSIONS

REFERENCES

\section{INTRODUCTION}

It has been recognized for many years that the stomach functions as a reservoir which aids homeostasis by allowing gradual emptying of nutrients for digestion and absorption in the intestines over a period of some hours after meals. In addition to this role, the stomach is the site of important steps in the digestion of proteins and provides an acidic environment which depresses or eliminates the activity of microbes consumed with the diet. The function of the stomach has been very extensively studied, but in most cases from physiological or pathological viewpoints; studies of the latter have inevitably contributed centrally to the former. By contrast, the specifically nutritional factors which control gastric function have received much less thorough attention. The aim of the present review is to evaluate the nutritional stimuli for the physiological regulation of secretion, digestion and emptying in simple-stomached mammals, taking examples from studies in humans, pigs, dogs, preruminant calves and rats. A brief summary of relevant physiological mechanisms will be given at the beginning of each section.

\section{SECRETION}

Gastric secretions are often measured in relatively non-specific terms, but include bicarbonate, hydrochloric acid from the parietal (oxyntic) cells of the fundic region, pepsinogens from the chief cells also in the fundic region, protective mucoproteins from most of the stomach mucosa, and shed epithelial cells from all regions. The regulation of these secretions is brought about by a complex interplay of neural, hormonal and nutritional stimuli.

\section{ACID SECRETION : PHYSIOLOGICAL ASPECTS}

Gastric acid secretion is classically considered to involve cephalic, gastric and intestinal phases. These processes are principally mediated by histamine, gastrin and acetylcholine which act directly on the parietal cell (Nicholl et al. 1985; Walsh, 1988).

The cephalic phase of acid secretion initiated by the sight, smell or thought of food appears to be largely mediated through release of acetylcholine at a peripheral level by the vagus, but the sensory receptors and the pathways involved are not well established. Central nervous system mediators are unknown. The cephalic phase makes a significant contribution to the overall response to a meal, especially in the first $0.5 \mathrm{~h}$.

The gastric phase of acid secretion includes the effects of raised intragastric pressure, 
distension and chemical stimulation of gastrin release. While distension appears to be important, raising the intragastric pressure may also increase secretion, largely through gastrin-independent mechanisms (Soares et al. 1977). The effects of distension may be mediated by neural pathways rather than gastrin release, as found for liquids by Soares et al. (1977). Chemical stimulation can be measured in humans by intragastric titration to constant $\mathrm{pH}$, or by multiple measurement of marker dilution: both methods give similar results. In animals fully-innervated pouches can be formed surgically. Secretion has most often been measured, however, by simply following $\mathrm{pH}$ changes; these are a net result of hydrogen ion inputs from acid and the buffering capacity of food, and are dependent on the relative proportions of secreted acid and food which have yet to be emptied into the duodenum.

The intestinal phase of acid secretion includes cases of both stimulation and inhibition. Intraduodenal infusion of peptone or liver extract caused an increase in gastric acid secretion that was apparently independent of gastrin (Isenberg et al. 1977). This may in part be due to absorbed amino acids, since intravenous infusions of amino acids in humans led to significantly higher acid secretion (Isenberg \& Maxwell, 1978). Introduction of fat or fatty acids into the intestine, by contrast, produces marked inhibition of gastric acid secretion (Christiansen et al. 1976, 1979), but the mechanisms involved require further study (Walsh, 1988). Hypertonic glucose solutions also stimulate gastric inhibitory polypeptide (GIP) secretion (Creutzfeldt et al. 1983) and inhibit acid secretion, whether given orally, intraduodenally or intravenously (MacGregor et al. 1976); however, whether comparable conditions occur in practice is perhaps doubtful. Acidification of the duodenum also inhibits acid secretion (Berstad \& Petersen, 1972); though secretin may be involved the amounts needed are higher than usually seen and there is evidence of the involvement of an enterogastric reflex pathway (Konturek \& Johnson, 1971).

\section{ACID SECRETION: NUTRITIONAL ASPECTS}

\section{The neonate}

The onset of acid secretion appears to be very early in life; the newborn pig, for example, is capable of secreting acid from birth and the capacity increases steadily with age during the first 4-5 weeks of life. Maximal outputs of acid per unit stomach weight were relatively constant in anaesthetized piglets following stimulation with betazole hydrochloride (Cranwell, 1985); acid secretion was greater when piglets were given access to solid food before weaning and then weaned onto solid food (accompanied by heavier stomachs) than in wholly suckled piglets. Studies in gastric-cannulated piglets either suckled or given a dry cows'-milk formula from $8 \mathrm{~d}$ of age by Decuypère et al. (1978) showed that suckled piglets had a higher acid concentration but this was partly because of a much higher concentration of lactic acid than in the weaned piglets, probably arising from microbial fermentation in the stomach. The observation was interpreted as related to the lower observed acidbuffering capacity of gastric contents of the weaned than the suckled piglets; acid-buffering capacity is a major factor influencing gastric acid secretion (Saint-Hilaire et al. 1960). Comparative aspects of the development of gastric secretion in piglets and humans were discussed by Cranwell (1986).

\section{Meal $p H$}

Gastrin and acid release appear to decline when the $\mathrm{pH}$ of a meal falls below 4 (Konturek et al. 1974); neutralization of gastric contents restores gastrin release. However, it is not known whether these effects are mediated by direct action in the antral gastrin cells or by altering the activity of such cells as somatostatin cells or mucosal neurons. 


\section{Distension and meal size}

Gastric distension by pectin-based liquid test meals increased acid secretion in early studies on humans by Hunt \& Macdonald (1952). Increasing meal size also raised the maximal acid response of Pavlov pouches in dogs (Brooks \& Grossman, 1970). However, while balloon distension of the fundus in humans was stimulatory in studies by Grötzinger et al. (1977), it appears to be inhibitory for the antrum (Schoon, 1988). Specific measurements of the effects of distension made with meals containing normal foods are not available, but it is of interest to note that meals with a high content of non-starch polysaccharides (NSP) tend to lead to greater volumes of gastric digesta. This appears to be partly a function of the water-associating properties of NSP, rather than increased acid secretion, as the intragastric $\mathrm{pH}$ was higher when NSP-enriched semi-purified diets were fed to pigs by Rainbird \& Low (1986b).

\section{Particle size}

The importance of the physical nature of food in stimulating acid secretion has been rarely assessed, but Lawrence (1970) noted that gastric $\mathrm{pH}$ of pigs was consistently higher when finely-ground rather than coarsely-ground barley-based diets were given to pigs. Subsequently, Lawrence (1972) showed that pigs given barley-based diets in wet form had lower gastric $\mathrm{pH}$ values than those fed dry. In the same study he also found that coarse bran supplementation of maize-based diets led to markedly lower $\mathrm{pH}$ values. In a comparison in humans of solid--liquid or homogenized meals made from steak, bread and ice-cream, Malagelada et al. (1979) found that gastric $\mathrm{pH}$ tended to be lower in the solid- liquid meals, which again suggests that large particles stimulate acid production, though the mechanism involved is not known.

\section{Meal size and frequency}

A combined study by Babouris et al. (1965) on changing both meal size and frequency in humans with duodenal ulcers showed that frequent small meals gave less variation in pre- and post-meal gastric $\mathrm{pH}$ because of more even stimulation of acid production.

\section{Dietary proteins, peptides and amino acids}

The stimulatory effects of dietary proteins, peptides and amino acids are well established. Protein-rich foods were found to be the most powerful stimulants (in proportion to their protein content) of acid secretion in dogs with Pavlov pouches, but they equally had the highest buffering capacity (Saint-Hilaire et al. 1960). In a similar study, a series of protein sources was given to dogs and acid secretion rose in the order gelatin $<$ casein $<$ gluten $<$ lactalbumin < lean beef (Kotrba \& Code, 1969). It is, however, difficult to assess whether these effects are due to protein per se, to the partial digestion products, peptides, or to their final products, amino acids, which begin to appear as soon as the protein enters the stomach, and which are potent secretogogues in humans (Richardson et al. 1976). It is of interest to note that Zebrowska et al. (1983) found much more gastric secretion (acid was not measured specifically) when a diet based on barley was given than a semi-purified diet with casein: the former led to much larger quantities of gastric peptides and amino acids than the latter, but it was also of much larger mean particle size (which would also be predicted to increase acid secretion). There is interesting evidence that the type of protein fed can markedly influence acid secretions in preruminant calves. Soya-bean flour has been found to reduce secretion markedly compared with fish protein (Williams et al. 1976), perhaps because it has a much lower buffering capacity than fish protein.

The solubility of a protein also appears to affect acid secretion: soluble soya-bean 
proteins induced a more rapid and larger acid secretion in pigs than insoluble soya-bean proteins (Decuypère et al. 1981).

Free amino acids delivered either orally, intragastrically or intravenously have been shown to be stimulants of gastrin and acid; of these phenylalanine and tryptophan are the most potent in both dogs and humans (Strunz et al. 1978; Taylor et al. 1982). The specific composition of amino acids may determine the net effect of mixtures on the pattern of release of regulatory peptides (Taylor et al. 1982). Gastric instillation of amino acids was responsible for most of the stimulation seen by Feldman et al. (1978) since intravenous administration of gastrin also caused similar levels of acid secretion during periods without instillation. However, reducing intragastric $\mathrm{pH}$ from 5.5 to 2.5 abolished the gastrin response to amino acids in humans but only partly reduced the acid response, indicating that amino acids stimulate secretion by more than one mechanism (Walsh et al. 1975). It is not clear what levels of free amino acids are found in the stomach under normal feeding conditions and hence it is difficult to know the extent to which free amino acids are normally stimulants of acid secretion. Furthermore, acid secretion has been induced in many of these studies by pentagastrin or histamine, so that the results are not immediately relevant to normal meal eating.

\section{Dietary carbohydrates}

Evidence that acid secretion is stimulated by carbohydrates is lacking; by contrast secretion was inhibited by $30 \%$ in dogs by addition of $200 \mathrm{~g}$ glucose $/ \mathrm{kg}$ to an oral meal, while neither serum gastrin nor GIP were affected: when the same amount of glucose was given intraduodenally, acid secretion fell by $80 \%$, with a corresponding increase in GIP (Creutzfeldt et al. 1983). It seems likely that this effect was initially mediated at the duodenal level and was the result of the hypertonicity of the glucose solution as noted by Ward et al. (1969) in humans. The roles of somatostatin, insulin and gastrin were examined in a similar study in humans by Sasaki et al. (1983). Carbohydrates classified as NSP appear to have a minimal effect on gastric secretion both in humans (Tadesse, 1986) and in pigs (Rainbird \& Low, 1986a,b), though they may have a buffering capacity. Furthermore, Petersen et al. (1985) have suggested that enteroglucagon is responsible for the inhibitory effect of glucose; plasma levels of this hormone were elevated after iso- and hypertonic glucose solutions were intrajejunally instilled, while there was no effect of equi-osmolar saline ( $9 \mathrm{~g}$ sodium chloride/l) solutions. In neither case were levels of gastrin or pancreatic glucagon altered.

\section{Dietary fats}

The presence of fat in the intestine produces a more profound and prolonged inhibition of acid secretion than acidification, and it is associated with delayed gastric emptying, as will be discussed later. Arachidonic acid administered into an artery has also been identified as having marked iphibitory properties (Konturek et al. 1979). Oral olive oil was found to have a negligible stimulatory effect when given to dogs with vagally-innervated gastric pouches, compared with proteins (Kotrba \& Code, 1969), while fat-rich foods such as cream and eggs resulted in much lower acid production than high-protein foods, in similar studies by Saint-Hilaire et al. (1960).

\section{Beverages}

Beverages have markedly different effects on acid secretion as noted by McArthur et al. (1982) who compared nine types by intragastric titration in humans: the order of increasing secretion was water $<$ coke $<$ Sanka $<7$-Up $<$ tea $<$ Tab $<$ coffee $<$ kava $<$ beer $<$ milk. The protein contents of milk, and beer to a lesser extent, are important contributors to the 
effects. Alcoholic drinks such as wine (especially red) have been found to be stimulatory (Petersen et al. 1986); the factor involved was not clear but $120 \mathrm{ml}$ ethanol/l on its own had little effect in this study. By contrast, Lenz et al. (1983) found that a $50 \mathrm{ml}$ ethanol/1 solution was stimulatory, but higher levels were less so. Decaffeinated coffee was observed to have a higher acid-simulating effect than a peptone meal, as assessed by intragastric titration, in humans, but the factor responsible was not identified (Feldman et al. 1981). Various spices have been observed to increase acid secretion, such as red and white pepper (Myers et al. 1987), but again the chemical nature of the stimulant has not been identified.

\section{Stimulatory effects of whole foods}

The acid stimulatory effects of typical cereals, fruits, vegetables, milk, meat and eggs were examined by Saint-Hilaire et al. (1960) in six dogs with vagally-innervated gastric pouches. The responses varied markedly, but are difficult to interpret fully, other than to note that high-protein foods tend to be stimulatory, and high-fat foods inhibitory, and plant foods generally elicit lower responses than animal foods.

The effects of foods fed to farm animals such as pigs on gastric secretion have been little studied in recent years. Early work in the Soviet Union, summarized by Kvasnitskii (1951), indicated that silages, especially those made from lucerne (Medicago sativa), were more potent stimulants of total gastric secretion than cereals, with concomitant increase in free hydrochloric acid output but a decrease in pepsin output. Gridin (1956), again working with pigs, observed that bulky feeds such as melon and sugar beet had a greater stimulatory effect than lucerne, while the effects of skim milk were very small.

In summary, the physiological control of gastric acid secretion is mediated by a number of hormones or peptides, whose relative importance is not clearly established, except for the dominance of gastrin. The effects of foods of different chemical and physical composition are very diverse and physical factors such as meal size and particle size add further to the complexity of the factors involved.

\section{BICARBONATE SECRETION}

Although it has been known for some time that bicarbonate is secreted by the stomach, its potential quantitative importance has been little studied. It has been postulated that the role of bicarbonate is to aid disposal of luminal acid and to provide protection of the mucosal cells against this acid (Flemström \& Garner, 1982). Rees et al. (1982) concluded from studies in healthy humans that bicarbonate secretion may occur at a rate of $10-20 \%$ of basal acid secretion. Konturek et al. (1985) observed that instillation of acid into the stomach of dogs with antral and fundic pouches led to significant increases in bicarbonate secretion, but there was no significant effect of a meat meal, possibly because acid secretion was continuing (although ranitidine had been given to suppress acid secretion).

\section{PEPSINOGEN SECRETION}

Even today we lack a full understanding of the specific neural and hormonal factors responsible for pepsinogen secretion, of the intracellular mechanisms of stimulus-secretion coupling and of the mechanism of release of the granular contents, as discussed in detail by Hersey et al. (1984). By contrast there is a considerable literature on the biochemistry of pepsins; it is apparent that many species are able to secrete several forms with different $\mathrm{pH}$ optima, which correspond to the need for activity from near neutrality immediately after a meal to the low $\mathrm{pH}$ found several hours later.

Many secretogogues for pepsinogen have been identified but there may well be 
differences between species. These include cholinergic and adrenergic neurotransmitter agents, cholecystokinin (CCK) octapeptide, caerulein, gastrin, secretin, vasoactive intestinal peptide (VIP), cyclic AMP and hyperosmolarity (Gilbert \& Hersey, 1982). Calcium may also be required for secretion. By contrast, GIP, neurotensin and somatostatin all appear to inhibit pepsinogen secretion. However, specific mechanistic links between nutrients present in the stomach and duodenum and pepsinogen secretion are lacking at present.

\section{The neonate}

Studies in several animal species show that the amounts of pepsins present at birth are very low but that they increase rapidly $2-3$ weeks later. However, newborn pigs contain the proteinase chymosin (EC 3.4.23.4), and the levels of this enzyme gradually decline after birth (Foltmann et al. 1981). Maximal outputs of pepsin per unit stomach weight increased over several weeks in the studies by Cranwell (1985), and the values were greater for creepfed than suckled pigs, corresponding with greater stomach weight and higher acid secretion in the former group. Acid secretion developed relatively constantly from birth, unlike pepsinogen which developed slowly for the first 3-4 weeks of life, while the total milkclotting enzyme activity increased as acid secretion developed (Cranwell et al. 1987). Decuypère et al. (1978) observed similar developmental changes in piglets. In calves it seems that prorennin is the major proteinase at birth, but pepsinogen secretion may also occur at or soon after birth (Henschel, 1973); only pepsinogen is secreted when calves are older. The transition from prorennin to pepsinogen secretion has not been conclusively related to a specific dietary change.

\section{Growing pigs}

Early studies by Reimann et al. (1967) and Lawrence (1972) in pigs, and Malagelada et al. (1979) in humans, on the effects of the physical form of the diet highlight an important issue; measurement of pepsin (EC 3.4.23.1) concentration in digesta is not a reliable index of the rate of secretion, because orally consumed water levels may vary, just as gastric emptying rates may vary. It is also possible that pepsin may bind to some dietary ingredients and may, thus, not be measured in the assay, though this has not been generally demonstrated. A partial solution to the problem of estimating total pepsin output in $40 \mathrm{~kg}$ pigs by Zebrowska et al. (1983) was to measure activity in the digesta of pigs fitted with reentrant cannulas in the proximal duodena. Under these conditions pepsin output was twice as high for a barley-fishmeal diet as for a semi-purified diet based on starch and casein containing the same amount of protein; the amount of gastric secretion was also twice as high for the former as for the latter diet. This has been confirmed in pigs with gastric pouches by P. D. Cranwell, A. G. Low and I. E. Sambrook (unpublished results). As suggested earlier in the present review, the greater acid production may have been the result of a much larger quantity of peptides in digesta of pigs given the barley-fishmeal diet, which in turn may have been related to the higher pepsin activity. This provides evidence of an integrated process of acid and pepsin secretion but it is not clear which of these processes is the initiator.

Pepsin output has been measured in pigs using gastric pouches by several Russian groups. Kvasnitskii (1951) noted more activity by night than by day when pepsin was measured in terms of the length of Mett's sticks digested by the juice. He also found that digestive activity was higher for a basal barley-based diet than for those to which soya-bean or lucerne silage had been added, while acid output showed an inverse relationship; by contrast similar measurements in the gastric contents showed a more predictable positive relationship between pepsin and acid concentrations. The discrepancy was explained as 
being due to the excessively high acid content of gastric pouch secretion exerting an inhibitory effect on pepsin activity under the assay conditions employed.

Bakeeva (1962) demonstrated that as the protein content of the diet for pigs was increased so the amounts of pepsin and acid secreted from gastric pouches rose. There is also some evidence that qualitative changes in the dietary protein are important; studies in dogs by Storozhuk (1968) showed that peak concentrations of pepsin occurred in the first hour for egg white, the second for milk and meat, the third for fish and the fifth for egg yolk. This implies that each protein source leads to its own pattern of pepsin secretion, and corresponding acid output.

In spite of the considerable knowledge about the numerous forms of pepsinogens which are secreted by the stomach, there is little information about how the proportions produced may be influenced by diet; it seems possible that those with a high $\mathrm{pH}$ optimum operate preferentially immediately after a meal when gastric $\mathrm{pH}$ is high, and subsequently those with a lower optimum predominate. In practice, assay procedures used under conditions of normal nutrition have not allowed such distinctions to be made.

\section{MUCUS SECRETION}

There has been much interest in recent years in the role of mucoproteins in the stomach. It is now recognized that mucoproteins together with bicarbonate form a protective layer adjacent to the epithelial surface so that under normal conditions acid and pepsin erosion of the mucosa (other than the cells of the gastric glands, which have a resistant membrane) is avoided. Much is known about the structure and properties of the mucoproteins and their association with bicarbonate as reviewed by Allen \& Garner (1980); while it is well established that drugs may modify the mucosal structure and mucus biosynthesis, specific effects of foods on these processes do not appear to have been examined.

\section{PROTEIN SYNTHESIS AND TURNOVER}

Although the study of protein turnover is technically complex, and absolute values need to be interpreted with caution, as discussed by Simon (1989), it is evident that the stomach is the site of very high levels of protein synthesis in pigs. Fractional rates (/d) of $0 \cdot 27$ for 25 $\mathrm{kg}$ pigs were found by Edmunds et al. (1978), 0.19-0.36 in $50 \mathrm{~kg}$ pigs (Simon, 1989), and $0.25-0.54$ in growing pigs for diets with $160 \mathrm{~g}$ crude protein (nitrogen $\times 6.25) / \mathrm{kg}$ and $0.21-0.35$ for diets with $40 \mathrm{~g}$ crude protein $/ \mathrm{kg}$ (Simon, 1989). Thus, the stomach may account for about $20 \%$ of the total protein content of the gut, and it may be the site of $8-14 \%$ of the total protein synthesized there daily (Simon, 1989). At present no comparable information is available for humans.

\section{VOLUME OF SECRETION}

It is technically very difficult to measure the total volume of gastric secretion: clearly when a pouch is surgically formed of a small part of the organ its secretion will not be representative of the whole and it is unaffected by direct physical effects of food. Measurement of gastric effluent is difficult because of the risk of disturbing bile flow if a cannula is located at the pylorus. Thus, Zebrowska et al. (1983) placed a re-entrant cannula immediately distal to the bile duct of $40 \mathrm{~kg}$ pigs and measured flow of digesta on diets with either barley and soya-bean meal (A) or casein and starch (B). After subtraction of the amounts of diet and water eaten, and estimates from other work of salivary and biliary secretion, it was calculated that in $24 \mathrm{~h} 81$ and 41 of secretion occurred for diets A and B respectively. This assumed no absorption of secretions anterior to the cannula; 
corresponding estimates of pepsin output were 3 and $1.5 \mathrm{~kg}$. Roy (1980) has estimated that abomasal secretion in calves suckling $3.621 \mathrm{milk} / 12 \mathrm{~h}$ is about $15 \mathrm{ml} / \mathrm{kg}$ live weight.

\section{DIGESTION}

\section{PROTEINS}

The principal hydrolytic enzyme active in the stomach is pepsin, in one or more of its forms, though in the immediate post-birth period rennin or chymosin are also of importance as noted earlier. The specificity of pepsin suggests that the peptides resulting from gastric digestion will tend to have phenylalanine, tyrosine and leucine at one or other terminal.

In one of the earliest studies on the time course of gastric digestion of proteins, Zebrowska (1968) gave rats a protein-only meal, anaesthetized them 1, 2, 3 or $4 \mathrm{~h}$ later, and then collected and analysed the digesta. Casein and $\alpha$-protein were more completely hydrolysed and the digesta left the stomach faster than raw or heated soya bean. A series of studies with 28-d-old piglets killed $1 \mathrm{~h}$ after feeding showed that the appearance of trichloroacetic acid (TCA)-soluble $N$ in gastric contents was slower for bovine milk proteins than for fish proteins (Newport, 1979), isolated soya-bean protein (Newport, 1980) or a whey-supplemented milk (Newport \& Henschel, 1984); heat-damaged milk proteins were less rapidly digested than undamaged proteins (Braude et al. 1971).

Studies in older pigs with gastric cannulas have shown that the amounts of TCA-soluble $\mathrm{N}$ increased from 11 to $55 \%$ of total $\mathrm{N}$ during $7 \mathrm{~h}$ after a meal (Cuber et al. 1980). Various sources of supplementary NSP did not affect the rate of appearance of TCA-soluble N according to Rainbird \& Low $(1986 b)$, who also used pigs with gastric cannulas. Measurements of the amount of TCA-soluble $\mathrm{N}$ leaving the stomach of growing pigs were made by Zebrowska et al. (1983) using pigs with a cannula in the duodenum, proximal to the pancreatic duct. During a $12 \mathrm{~h}$ period, the proportion of TCA-soluble $\mathrm{N}$ rose from 13 to $50 \%$ for a diet with casein as the only protein source, while it remained at approximately $50 \%$ for a barley-soya-bean diet.

Marked effects of technological treatment of milks on gastric digestion in minipigs has been found by Kaufmann (1984a,b), Meisel \& Hagemeister (1984) and Pfeil (1984). These studies show that major differences in the pattern of digestion and subsequent metabolism of foods can be achieved by altering their processing, and specific physiological or clinical aims may, thus, be met.

\section{CARBOHYDRATES}

Enzymic hydrolysis of carbohydrates in the stomach is very limited. Although theoretically the $\mathrm{pH}$ in the stomach is high enough for the action of salivary amylase $(E C$ 3.2.1.1), the amounts secreted appear to be very small, at least in pigs (Corring, 1980). Several authors have noted the disappearance of glucose proximal to the pancreatic duct of pigs (for example, Zebrowska et al. 1983); this may be the result of both salivary amylase and nonenzymic hydrolysis. However, this is unlikely to have been due to active gastric absorption of sugars (Low \& Rainbird, 1986), though at very high concentration they may be absorbed passively (Keegan \& Devilliers, 1980). More likely explanations for this disappearance are absorption from the duodenum, or microbial fermentation, as will be discussed later.

\section{FA T}

It has become clear in recent years that fat digestion occurs in very young children (including premature infants) as a result of a lingual lipase with a $\mathrm{pH}$ optimum of $5 \cdot 4$, and a specificity which results in the release of di- and monoglycerides, glycerol and free fatty 
acids from tripalmitin (Hamosh et al. 1978). The activity of this enzyme is still marked at pH 3.0 and it is resistant to lower pH conditions in the presence of lipids (Fink et al. 1984). Its substrate specificity (mainly towards medium-chain triglycerides) was studied in detail by Liao et al. (1984). However, the quantitative nutritional aspects of lingual lipase activity are not yet adequately understood.

Gastric lipolysis has also been observed in mature minipigs by Timmen \& Precht (1984) who found that partial glycerides and free fatty acids formed $15-30 \%$ of gastric fat: the highest values were found for ultra-high-temperature (UHT) milk $120 \mathrm{~min}$ after a meal and for pasteurized milk $260-360$ min after a meal. The gastric $\mathrm{pH}$, possible damage to the milk fat globule membranes (non-homogenized milk), and the existence of secondary membranes around casein (homogenized milk) were all found to be important factors determining lipolysis. The quantitative importance of gastric lipolysis in humans remains unclear.

\section{MICROBIAL DIGESTION}

The existence of an actively metabolizing bacterial population has been demonstrated in many species of animals as well as man, but the quantitative significance of this activity is very difficult to estimate in non-ruminants because the principal products of fermentation, volatile fatty acids and lactic acids from carbohydrates, and ammonia and amines from proteins, may be formed in almost all regions of the digestive tract. Measurement of concentrations in digesta does not give an accurate picture of the rate of their formation because absorption is continuing at the same time. Nevertheless, Clemens et al. (1975) showed that the highest concentrations of lactic acid were found in the stomach of pigs and the stomach and small intestine had the lowest concentrations of volatile fatty acids. GiusiPerier et al. (1989) found that amounts of lactic acid absorbed from growing pigs were less than $10 \%$ of the amounts of glucose and they considered that most of the lactic acid had probably arisen from metabolism during absorption rather than from microbial metabolism; in one treatment lactic acid was given as part of the diet and less than $20 \%$ was recovered in the hepatic portal vein after absorption, again indicating that metabolism makes estimates of lactic acid production difficult. Microbial activity in the stomach of pigs has recently been reviewed by Ratcliffe (1985).

\section{GASTRIC EMPTYING}

\section{PHYSIOLOGICAL ASPECTS}

The two functional compartments which are important in determining gastric motility or emptying are the proximal fundus, which acts as a reservoir of food, and the distal antrum which is responsible for the physical mixing and breakdown of solids.

The emptying of liquids is thought to be largely a function of the pressure gradient between the stomach and the duodenum. Intragastric pressure arises from muscular contractions in the fundus, broadly grouped into those which are sustained, and those which are rapid and phasic; only the former appear to be important in this context. This sustained motility is in a receptive state during meal consumption, allowing the volume to increase, without raising intragastric pressure; this is under vagal control. Increases in the amplitude of the sustained contractions lead to increased pressure and emptying of liquids, partly under the influence of CCK.

The emptying of solids usually only occurs when they have been reduced to relatively fine particles $(<2.0 \mathrm{~mm}$ in size, Meyer et al. 1979) in the distal stomach. In the antral or distal region motility takes the form of cyclic changes, originating in the pacemaker cells in the 


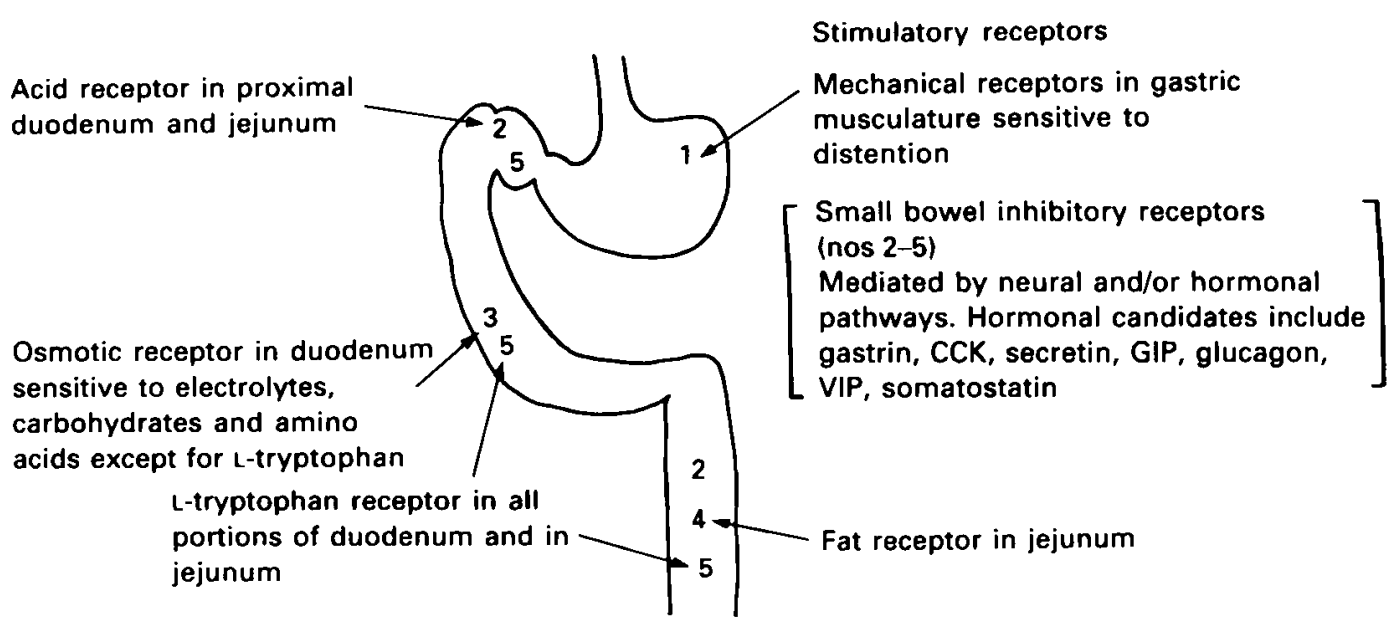

Fig. 1. A scheme of the physiology of gastric emptying (from Minami \& McCallum, 1984).

greater curvature, at a rate of $3-4 / \mathrm{min}$, and these determine the frequency and velocity of antral contractions some of which become peristaltic waves. The initiation of this activity is caused by an excitatory stimulus such as a neurotransmitter, in response to the size and composition of a meal; however, the detailed aspects of this mechanism remain to be elucidated. These contractions mix and grind food, and as the wave approaches the distal antrum, the terminal antrum and pylorus close; large solids are milled and reduced further in size. Vagal and sympathetic neural pathways are involved in the distal stomach, and gastrin also plays a role, facilitating generation of action potentials (Morgan et al. 1978). Those solids which cannot be broken down to a sufficiently small size are emptied, through another form of electrical activity, the migrating myoelectric complex, during fasting periods. This complex is thought to be controlled by the central nervous system, with motilin as an initiating hormone, and possibly with gastrin as an inhibitor (Thomas et al. 1980). Further aspects of the physiology of gastric emptying were reviewed by Kelly (1980) and Burks et al. (1985).

\section{MEASUREMENT}

Most non-invasive methods of measurement in man fall into three categories: intubation (gastric and duodenal), radiological (using radio-opaque meals) and radioisotopic (using tagged solid foods, usually with technetium 99). In experimental animals it is possible to place cannulas in the stomach, or in the proximal duodenum, though in the latter case the presence of bile and sometimes pancreatic secretions is a problem. Surgical intervention also carries the risk of abnormal function, because the physical presence of a cannula fixed to the abdominal wall may reduce the mobility of the gut, and because of the possible severance of nerves. However, cannulation of the greater curvature region did not lead to any observable abnormalities in gastric muscle motility in pigs according to Cuber et al. (1980), whereas re-entrant cannulation in the proximal duodenum led to disturbed patterns (Laplace, 1980).

The serial test meal method has been used for most of the classical studies on gastric emptying with liquid meals in humans (Hunt \& Spurrell, 1951). A non-absorbable marker is added to the meal and the subject drinks the same meal on different days; at different times after the meal the entire contents are aspirated. The dilution of the marker and the 
volume removed give a combined index of gastric secretion and emptying. Elaborations of the procedure include the use of a second marker to determine interim volumes of digesta without total removal of the contents, and tubing sufficiently large to aspirate solids, including both gastric and duodenal digesta.

Radiological methods, generally using barium meals, are qualitative indicators of emptying; the barium tends to move with the liquid phase, or may dissociate from the solid phase into which it is sometimes impregnated. Quantitative measurement of solid and liquid emptying is, thus, impossible.

Radioisotopic methods usually involve consumption of ${ }^{99 m}$ technetium bound in chicken liver and ${ }^{11}$ indium, to mark solid and liquid phases respectively. By means of gamma cameras, which can simultaneously follow emptying of two markers of different energies, emptying of liquid and solid phases can be measured under physiological conditions, with computerized minute-by-minute recording. It is important to realize that these methods provide a two-dimensional view of a three-dimensional process, because the intensity of radiation will depend on the depth within the stomach from which it arises, giving rise to variations in counting efficiency. It is also apparent that ${ }^{11}$ indium may have some affinity for solids, and to differing extents for different foods. Nevertheless, these methods have become very widely used as diagnostic tools for studies of gastric dysfunction, as reviewed by Minami \& McCallum (1984).

\section{NUTRITIONAL ASPECTS}

\section{Influence of meal volume}

The earliest views about the normal pattern of gastric emptying were that the rate was proportional to the degree of distension of the stomach, but the view that the pattern is exponential has been dominant. However, Hunt \& Macdonald (1954) observed that large liquid test meals only empty exponentially during the middle part of the period of measurement. Hopkins (1966) re-evaluated many previous studies and thought that the relationship between meal volume and emptying was best described by the square root of the volume remaining in the stomach, particularly in the later stages of emptying; however, Hinder et al. (1976) considered that at this stage endogenous secretions became a major contributor to total digesta volume, and that if these are taken into account, the pattern is linear. Further re-examination of the literature led Stubbs (1977) to conclude that meal volume is a major determinant of emptying rate. However, the picture is complicated by the variety of methods of measuring gastric emptying, as noted by Elashoff et al. (1982) who considered that standard methods are needed and that the best description of emptying is provided by a power exponential curve. The continuing utility of the exponential model has been stressed by Smith et al. (1984).

It is important to recognize that the pattern of emptying of meals with a substantial solid content appears to be much more complicated than that of liquid meals, as noted by Laplace et al. (1983); linear initial emptying patterns were found with increasing total meal size in dogs by Leib et al. (1986), and when the volume of water consumed with a meal by pigs was varied by Low et al. (1985). It is clear that the emptying of solid and liquid components can follow very different patterns, as found by Hinder \& Kelly (1977). Normal meals have a complex and varied physical and chemical constitution which alters greatly during gastric digestion, which includes major secretory inputs. The role of the various physical and chemical factors involved is reviewed later. It seems impossible at present to provide satisfactory mathematical descriptions of the rate of gastric emptying of the components of the meal because of the complexity of the system and the interactions which are likely to occur between its various components. 


\section{Particle size}

The antral region of the stomach is the site of propulsion, grinding and retropulsion of solids until they are sufficiently small to pass into the duodenum; Meyer et al. (1979) found that virtually all the meal emptied into the duodenum of normal dogs had a particle size of $2 \mathrm{~mm}$ or less, while dogs with ulcers emptied larger-sized meat particles. A similar conclusion was drawn by Holt et al. (1982) in studies in humans; small cubes $(3 \mathrm{~mm})$ of liver emptied faster than large cubes $(10 \mathrm{~mm})$ when assessed by gamma camera; $50 \%$ emptied in 50 and $70 \mathrm{~min}$ respectively. Comparison of the rates of emptying of labelled liver, of either 0.25 or $10 \mathrm{~mm}$ particle size, by Weiner et al. (1981) confirmed more rapid emptying of the small particles: in addition it was noted that noodles emptied faster than liver (half-times of 52 and $82 \mathrm{~min}$ respectively). When ordinary solid-liquid (S) and homogenized $(\mathrm{H})$ meals of sirloin steak, bread, butter, ice-cream and chocolate syrup and water were given to humans, initial gastric emptying was faster for $\mathrm{S}$ meals (together with higher gastric secretion) but for most of the period of measurement $\mathbf{H}$ meals emptied faster (Malagelada et al. 1979). Meisel \& Hagemeister (1984) also found that homogenized milk emptied faster from pig stomachs than the same milk in non-homogenized state. The requirement for small particle size for emptying of solids is consistent with the many observations that liquids generally empty faster than solids from the stomach as they are more or less independent of the comminutory activities of the antrum. This was found by Notivol et al. (1984), who also noted that women emptied solids and liquids more slowly from their stomachs than men. Furthermore, a relationship between gastric emptying and the phase of the menstrual cycle was seen.

\section{Viscosity}

There has been considerable interest in recent years in the effect that increasing the viscosity of a meal may have on gastric emptying. This stems from observations that increased viscosity in the gut may be responsible for the property of NSP to reduce the rate of glucose absorption, which is of particular interest in the control of diabetes. Holt et al. (1979) found that pectin and guar gum both delayed gastric emptying. Differences between this finding and some earlier studies may be due to differences in the viscosity of the test meals used; both here and in many other publications insufficient information is given on how the NSP sources were hydrated and the specific conditions under which viscosity was measured. Konjac (Amorphophallus rivieri Dur.) mannan (Ebihara et al. 1981) and locust bean (Ceratonia siliqua L.) gum (Tsai \& Peng, 1981) have been shown to delay gastric emptying of liquid meal in rats. Further evidence for delayed gastric emptying of liquid meals has been provided by Schwartz et al. (1982) and Sandhu et al. (1987) for pectin in humans, by Russell \& Bass (1985) for guar gum in dogs, and for carboxymethyl cellulose and raffinose (but not pectin) in humans by Tadesse (1986).

By following the appearance of ${ }^{24} \mathrm{Na}$ in peripheral blood (using an external radiation monitor), Wilmshurst \& Crawley (1980) concluded that guar gum delayed the emptying of a low-energy milky drink. By contrast Morgan et al. (1985), who measured gastric emptying by assessing peripheral blood paracetamol levels, found no effects of guar gum on protein meals containing cooked lean beef or fat (double cream). Potato granules were used by Ehrlein \& Pröve (1982) to increase the viscosity of semi-liquid meals given to dogs; the effect was to delay gastric emptying according to a sigmoid pattern, while that of the control was exponential.

Long-term supplementation ( 2 months) of diets for humans with guar gum and wheat bran by Ray et al. (1983) led to decreased rates of gastric emptying of labelled solids and liquids in a meal of water and egg sandwich. Brown et al. (1988), using ${ }^{99} \mathrm{mTc}$ sulphur 
colloid homogenized with beans, observed that guar gum delayed gastric emptying of the label (assumed to tag the solid phase) in rats during the first hour after a meal. Because the label was not specifically tagged to the beans the marker may have remained partly in the liquid phase. It is always difficult to interpret the relative movement of liquid and solid markers used to monitor gastric emptying because of inadequate tagging, or of the solubilization of the material to which the label is attached and, hence, its emptying in the liquid phase.

Problems of identifying liquid phases were overcome by Rainbird \& Low $(1986 a, b)$ who examined the effects of various levels of fully hydrated guar gum (Rainbird \& Low, 1986a) and wheat bran, carboxymethylcellulose, high methyl citrus pectin and guar gum granules (Rainbird \& Low, 1986 b) on gastric emptying in pigs. Quantitative direct recovery of gastric contents over a $4 \mathrm{~h}$ post-prandial period was used. The NSP sources reduced the rates of gastric emptying at various times of observation of the meals as a whole but the emptying of the solid phase was not delayed. Rainbird (1986) compared gastric emptying of a normal meal, a low-energy milky drink and a glucose drink in pigs, and again found that guar gum markedly delayed liquid emptying, as seen earlier by Wilmshurst \& Crawley (1980) (and by various authors for glucose drinks), but solid emptying was unaffected.

By contrast with studies which demonstrated that viscous NSP sources may delay gastric emptying, Potkins \& Lawrence (1985) observed that guar gum and pectin accelerated emptying in pigs. The meals were based on barley, with particle sizes of $1.56 \mathrm{~mm}$ or less (fine) or $4.8 \mathrm{~mm}$ or less (coarse). Fine grinding also accelerated emptying. An explanation for this may lie in the finding by Meyer et al. (1986) that guar gum accelerated the emptying of Teflon spheres (which are insoluble as is barley) in dogs, though emptying of liquids was delayed and solids from liver was unaffected. In addition it was noted that the particles of liver which emptied from the stomach were significantly larger when guar gum was added to the meal. The authors considered that hydrodynamic factors were the cause of this effect; it was suggested either that guar gum suspended the spheres so that they remained in a central region of the stomach where they were expelled by each antral contraction, or that viscosity reduced the rate of movement to a storage region of the antrum. Other possible, though perhaps less likely, explanations for the effects seen by Meyer et al. (1986) were given by Pröve \& Ehrlein (1982) who suggested that the depth of peristaltic indentation of the stomach is of central importance in the regulation of emptying of viscous meals.

Present understanding indicates that the role of viscosity in gastric emptying appears to be mainly confined to the liquid phase of the digesta. More studies under varied experimental conditions are needed to clarify the issue, in view of the interest in the use of soluble NSP to improve management of diabetes and for lowering blood lipids.

\section{Osmolarity}

For many years it has been recognized that the higher the osmolarity of solutions in the stomach, the more gastric emptying is delayed. Though Hunt \& Knox (1968a) reviewed the evidence for the existence of duodenal osmoreceptors, and their properties, much remains unclear about their histological and functional nature. Meeroff et al. (1975) provided evidence that the receptors are localized in the duodenum only. The possibility that the response of these receptors might depend on shrinkage and swelling of the lateral intracellular space around the enterocytes was put forward by Barker et al. (1978).

Hunt \& McHugh (1982) found that EDTA in test meals of water slowed gastric emptying in humans and monkeys. When the binding sites of the EDTA were loaded with Ca before it was given in the test meal there was little effect on gastric emptying; it was suggested that EDTA takes up Ca from tight junctions in the duodenal epithelium, providing a signal for slower gastric emptying, and that this mechanism might apply to fats, carbohydrates and 
proteins acting on the same receptor. When liquid nutrient diets with a range of osmolarities between 340 and $700 \mathrm{mOsm} / \mathrm{kg}$ were given to pigs by Case et al. (1981) there were no effects on gastric emptying rate 30 or $60 \mathrm{~min}$ after feeding, and gastric contents of all pigs converged towards $450 \mathrm{mOsm} / \mathrm{kg}$. Similarly, Low (unpublished results) found that diets of very different osmolarity given to pigs (containing either barley and fishmeal, or starch, sucrose and casein) all led to gastric and duodenal digesta of approximately constant osmolarity. It seems possible, therefore, that under relatively normal nutritional conditions the gut is able to adjust its environment to relatively constant conditions and that the effects of changes in the osmolarity of the diet on gastric emptying may not be important.

Acids

A wide range of strong and weak acids all delayed emptying of liquid test meals in proportion to their concentration in studies by Hunt \& Knox (1972). Organic acids appear to inhibit emptying in proportion to the number of carboxylic groups and molecular weight in dogs (Blum et al. 1976). There appear to be post-pyloric receptors to acids in humans and dogs, and also gastric receptors in humans, but little is known of the mechanisms which regulate emptying patterns in response to acid intakes in meals, or of their importance under normal nutritional conditions.

\section{Lipids}

The general observation that fatty acids delay gastric emptying was confirmed by Hunt \& Knox (1986b) who found that increasing the chain length of fatty acids up to fourteen carbon atoms led to progressively slower gastric emptying of test meals, with decreasing effectiveness for longer chains. Fatty acids are more effective than their corresponding dior triglycerides in delaying gastric emptying, while non-hydrolysable triglycerides are without effect (Cortot et al. 1982), suggesting that it is the digestion products of triglycerides acting in the duodenum which are of particular importance.

When large cereal-based meals were given to pigs by Low et al. (1985), maize oil reduced the rate of gastric emptying of solids and liquids during the second hour after the meal, indicating that inhibition of gastric emptying by lipids is not confined to liquid meals. Rates of emptying of lipid in humans and in dogs varied with the physical position of the lipid in the food matrix; extracellular lipid emptied mainly as an oil, while intracellular lipid mainly remained in the food $(66 \%)$ or was in the form of an emulsion (Meyer et al. 1986). Homogenization of a lipid-containing meal led to the same rates of emptying of lipid and aqueous phases, indicating that the physical form in which lipid is consumed is important (Cortot et al. 1979). A further indication that the physical environment may be important in the gastric emptying of lipid was shown by Trout et al. (1978), who found that lipid emptied from the stomach of rats more slowly than glucose, but when xanthan gum was added to the meal the emptying rates were the same.

It has recently been found that the presence of lipid in the ileum can markedly inhibit gastric emptying in humans (Holgate \& Read, 1985). A similar ileal infusion of lipids (as fatty acids) also inhibited gastric emptying in dogs, and increased peptide YY levels in blood (Pappas et al. 1986); infusion of peptide YY also delayed gastric emptying. Further evidence of mechanisms responsible for the effects of lipids comes from Keinke \& Ehrlein (1983) who found that oleic acid delayed gastric emptying in dogs and also caused marked reductions in antral motility and a narrowed opening of the pyloric sphincter. A possible role of $\mathrm{Ca}$ in delaying gastric emptying has been discussed by Hunt (1983); he proposed that anions of fatty acids displace $\mathrm{Ca}$ from a site on the tight junctions of the intestine, causing shrinking of the intercellular space, which may be the final common event in the duodenal regulation of gastric emptying. 


\section{Proteins and amino acids}

In a study on gastric emptying by Buraczewska et al. (1978) free lysine emptied from the stomach significantly faster than protein-bound lysine. Free amino acids have also been found to inhibit gastric emptying; phenylalanine and tryptophan had significant effects in rats (Mangel \& Koegel, 1984) and man (Fisher \& Hunt, 1977), tryptophan in dogs (Stephens et al. 1975) and L-, but not D-tryptophan, in cats (Cooke, 1978). Solutions of amino acids and peptides may contribute in a general way towards increased osmolarity of digesta and thus inhibit gastric emptying.

When test solutions of glucose, casein, partly hydrolysed gelatin or egg albumin, native or denatured, were given to humans, casein was emptied least rapidly and native egg albumin most rapidly. The emptying rates of casein, $\alpha$-protein, raw and heated soya bean in a semi-solid meal given to rats by Zebrowska (1968) were faster for $\alpha$-protein and casein than for soya bean. However, the emptying rates, $1 \mathrm{~h}$ after feeding in 28 -d-old pigs, of dried skim milk were lower than for fish-protein concentrate (Newport, 1979), single-cell protein (Newport \& Keal, 1980) and isolated soya-bean protein (Newport, 1980; Newport \& Keal, 1982 ); in each of these studies there were larger amounts of TCA-soluble $\mathrm{N}$ in the stomachs of the piglets fed on the non-milk diets. In older pigs, fitted with gastric cannulas, Laplace et al. (1984) found that gastric emptying of $\mathrm{N}$ in the first $2 \mathrm{~h}$ after feeding, from starchbased diets was faster when the protein source was fishmeal than wheat gluten or casein. Particular attention was paid in this study and the previous study (Laplace et al. 1983) to variation within and between animals, and to the most appropriate mathematical description of the patterns of gastric emptying. In two further studies by the same group, the emptying rate of wheat was faster than that of barley (measured using gastric cannulas; Laplace et al. 1985a), both of which were faster than maize measured after slaughter (Laplace et al. 1985b).

The rates of gastric emptying of a semi-purified diet containing casein as the only protein source, and a barley-soya-bean diet were compared in $40 \mathrm{~kg}$ pigs by Zebrowska et al. (1983). The initial rate of emptying of the casein diet was far more rapid than for the cereal diet; $76 \%$ and $28 \%$ respectively of intake left in the first hour after feeding. The reason for this is not clear though the finely-ground nature of the diet and the low levels of protein digestion products could both have accelerated emptying compared with the barley-soyabean diet.

Further evidence of the complexity of emptying of milk or casein-based diets is shown by the more rapid emptying of human milk than of infant formulas in infants (Cavell, 1981); this may be related in part to the amounts of whey protein as a percentage of total protein in bovine (20), porcine (50) and human (80) milks. Thus, Newport \& Henschel (1984) found that the gastric emptying rate of protein was highest for diets with a high whey:casein ratio. The nature of the curd formed in the stomach after consumption of bovine milk is also related to the rates of gastric emptying; soft curds from UHT-treated or cultured milk emptied faster than the hard curds formed from raw or pasteurized milk in the studies by Meisel \& Hagemeister (1984).

\section{Sugars}

A comparison of the rates of gastric emptying of sugar solutions in the young pig by Reed \& Kidder (1972) indicated that glucose and galactose emptied at the same rate, which was faster than for sorbitol and $\mathrm{NaCl}$ : increasing the glucose concentration depressed the rate of gastric emptying, and increased osmolarity of the digesta. Similarly, glucose inhibited gastric emptying in the milk-fed calf in the studies by Bell \& Razig (1973). Comparisons of the gastric emptying of glucose, D-xylose and fructose in rhesus monkeys 
(Moran \& McHugh, 1981) indicated that fructose was less inhibitory than glucose and Dxylose, and it also inhibited food intake less; this indicates that gastric emptying may be related to satiety (McHugh et $\mathrm{al}$. 1982) and this was supported by the finding that glucose delivery to the duodenum was constant, regardless of the concentration of the solution eaten (Brener et al. 1983): thus there may be a steady-state balance between glucose delivery to the duodenum and inhibition by the duodenum.

Disaccharides appear to have a less inhibitory effect on gastric emptying in rats than monosaccharides (Trout \& Bernstein, 1986) which is likely to be a result of their lower osmolarity, on a weight-for-weight basis. Sucrose supplementation of protein-based diets given to rats by Buraczewski et al. (1971) inhibited gastric emptying more than starch but less than lactose.

Starch

The physical nature of starch has been found to be a determinant of gastric emptying in growing pigs: Borgida \& Laplace (1977) found $40 \%$ more rapid emptying for extruded than for raw potato starch. Rates of purified wheat or maize starch emptying were compared in growing pigs by Laplace et al. (1983): the pattern of emptying was relatively similar for the two sources, but evidence was also presented that specific starch-protein interactions may also be important in determining gastric emptying.

More indirect indications of differences in the gastric emptying of starchy foods comes from studies in humans indicating that mashed potatoes leave the stomach faster than polished rice or white beans (Torsdottir et al. 1984). Cuber et al. (1981) found that starch in wheat emptied more rapidly from the stomach of pigs than starch in barley, but this may have been the result of components other than the starch itself.

\section{Non-starch polysaccharides}

While there is general agreement that cellulose and wheat bran are largely without effect on gastric emptying, there are numerous reports that soluble NSP do modify emptying patterns and these have been discussed earlier in the section on viscosity.

\section{Energy content of meals}

In recent years there has been much interest in the notion that gastric emptying of meals may proceed at a rate which allows a constant delivery of energy to the duodenum after a meal, at least in the early post-prandial period. Hunt \& Stubbs (1975) analysed most of the then available literature and concluded that this concept was generally applicable and that the effects seen were consistent with the known effects of fat, protein and carbohydrate on gastric emptying. Thus prediction of emptying rate could be made from a knowledge of the nutrient density of the meal. Support for this view came from the studies of McHugh \& Moran (1979) in monkeys, and Kalogeris et al. (1983) in rats. This concept was then extended by Hunt (1980) who suggested that gastric emptying was correlated with food intake. Further evidence for this was given by Castro (1981) who observed that the content of energy in the food residues in the stomach of rats at the initiation of a meal determined how much would be eaten, in terms of energy content, and the length of the inter-meal interval. This possible role of gastric emptying in satiety was linked conceptually with the satiety signals linked with the delivery of energy to the liver by McCann \& Stricker (1986)

By contrast with the view that gastric emptying is ordered so that the rate of energy delivery to the duodenum is relatively constant, there is a large body of evidence from animal studies that this is not necessarily so when larger and mixed meals are consumed. In a recent study in humans by Hunt et al. (1985) it was clear that increasing the energy density and meal volume led to increased rates of gastric emptying of energy into the 
duodenum. Gastric emptying studies in pigs by Zebrowska et al. (1983) indicated a far greater rate of emptying of semi-purified diets than cereal-based diets, when fed at the same total weight to pigs; the differences in energy concentration of the diets were much less than the differences in the rate of emptying. Furthermore, the patterns of emptying over a 12 $h$ period were biphasic and were also markedly different. This evidence indicates that the regulation of gastric emptying under normal meal-feeding conditions is more complex than hitherto thought, and cannot be simply described by the energy content of a meal.

\section{CONCLUSIONS}

The nutritional regulation of gastric secretion, digestion and emptying is a very complex process, as this account shows. The three processes are interdependent, and each is mediated by the neuro-endocrine system.

Present understanding of the effects of nutrients on gastric secretion comes mainly from studies where often ill-defined foods were given to animals with gastric pouches, in which the functional relationships of secretion, digestion and emptying are inevitably disturbed. Furthermore, the amounts of food given have often been small. Interactions almost certainly occur between foods, with consequences for gastric function, and these have not been studied systematically. Much of the early work on gastric emptying in humans was done with liquid test meals under closely-defined conditions; the relationships which emerged from this work doubtless underlie the responses of the stomach to normal meals but it is clear that a further major series of poorly-understood factors are involved when normal meals are eaten.

Major improvements have been made recently in the methods used to study gastric function, but at present so many different experimental procedures are being used that coherent models of the system are extremely difficult to construct. Nevertheless, it is apparent from the present review that gastric secretion tends to increase as the meal size, its particle size, its protein content and its pepsin-digestible protein content rise. This leads to a larger volume of digesta which may have a higher osmolarity as well as a lower $\mathrm{pH}$ (though protein buffering may reduce the fall in $\mathrm{pH}$ ). The latter two factors tend to depress gastric emptying, as does fat, through intestinal mechanisms. This is consistent with observed faster rates of emptying for meals of a liquid consistency, or those containing small particles, and of a low osmolarity. Thus, the physicochemical attributes of foods appear to be the dominant determinants of gastric function, but development of this general model to make quantitative prediction awaits further research.

\section{REFERENCES}

Allen, A. \& Garner, A. (1980). Mucus and bicarbonate secretion in the stomach and their possible role in mucosal protection. Gut 21, 249-262.

Bakeeva, E. N. (1962). [Digestion and metabolism in young pigs given qualitatively different food proteins.] Nauchnye Trudy Poltavsky Institut Svinovodstvo 22, $18-35$.

Babouris, N., Fletcher, J. \& Lennard-Jones, J. E. (1965). Effects of different foods on the acidity of the gastric contents in patients with duodenal ulcer. Il. Effect of varying the size and frequency of meals. Gut 6, 118-120.

Barker, G. R., Cochrane, G. McL., Corbett, G. A., Dufton, J. F., Hunt, J. N. \& Roberts, S. K. (1978). Glucose, glycine and diglycine in test meals as stimuli to a duodenal osmoreceptor slowing gastric emptying. Journal of Physiology 283, 341-346.

Bell, F. R. \& Razig, S. A. D. (1973). The effect of some molecules and ions on gastric function in the milk-fed calf. Journal of Physiology 228, 513-526.

Berstad, A. \& Petersen, H. (1972). Effect of duodenal acidification on the gastric secretory response to pentagastrin in man. Digestion 6, 193-204.

Blum, A. L., Hegglin, J., Krejs, G. J., Largiadèr, F., Saüberli, H. \& Schmid, P. (1976). Gastric emptying of organic acids in the dog. Journal of Physiology 261, 285-299. 
Borgida, L. P. \& Laplace, J. P. (1977). A comparative study of the gastric emptying of diets containing either raw or extruded potato starch in growing pigs. Annales de Zootechnie 26, 585- 593.

Braude, R., Newport, M. J. \& Porter, J. W. G. (1971). Artificial rearing of pigs. 3. The effect of heat treatment on the nutritive value of spray-dried whole-milk powder for the baby pig. British Journal of Nutrition 25 . 113-125.

Brener, W., Hendrix, T. R. \& McHugh. P. R. (1983). Regulation of the gastric emptying of glucose. Gastroenterology 85, 76-82.

Brooks, A. M. \& Grossman, M. I. (1970). Maximal acid response of Pavlov pouches to food and histamine. Gut 11, 153-157.

Brown, N. J., Worlding, J., Rumsey, R. D. E. \& Read, N. W. (1988). The effect of guar gum on the distribution of a radiolabelled meal in the gastrointestinal tract of the rat. British Journal of Nutrition 59, $223-232$.

Buraczewska, L., Zebrowska, T. \& Buraczewski, S. (1978). The rate of passage of synthetic lysine and dietary protein from the stomach to the intestine in pigs. Roczniki Nauk Rolniczych 99 B, 107-113.

Buraczewski, S., Porter, J. W. G., Rolls, B. A. \& Zebrowska, T. (1971). The course of digestion of different food proteins in the rat. 2. The effect of feeding carbohydrate with proteins. British Journal of Nutrition 25, 299 -306.

Burks, T. F., Galligan, J. J., Porreca, F. \& Barber, W. D. (1985). Regulation of gastric emptying. Federation Proceedings 44, 2897-2901.

Case, G. L., Lewis, L. D., Phillips, R. W. \& Cleek, J. L. (1981). Effects of osmolality of liquid nutrient diets on meal passage and nutrient absorption in Yucatan miniature swine. American Journal of Clinical Nutrition 34, $1868-1878$

Cavell, B. (1981). Gastric emptying in infants fed human milk or infant formula. Acta Paediatrica Scandinavica 70, $639-641$.

Christiansen, J., Bech, A., Fahrenkrug, J., Holst, J. J., Lauritsen, K., Moody, A. J. \& Schaffalitzky de Muckadell, O. (1979). Fat-induced jejunal inhibition of gastric acid secretion and release of pancreatic glucagon, enteroglucagon, gastric inhibitory polypeptide, and vasoactive intestinal peptide in man. Scandinavian Journal of Gastroenterology 14, 161166.

Christiansen, J., Rehfeld, J. F. \& Stadil, F. (1976). Effect of intrajejunal fat on meal-stimulated acid and gastrin secretion in man. Scandinavian Journal of Gastroenterology 11, 673-676.

Clemens, E. T., Stevens, C. E. \& Southworth, M. (1975). Sites of organic acid production and pattern of digesta movement in the gastrointestinal tract of swine. Journal of Nutrition 105, 759-768.

Cooke, A. R. (1978). Gastric emptying in the cat in response to hypertonic solutions and tryptophan. American Journal of Digestive Diseases 23, 312-315.

Corring, T. (1980). Endogenous secretions in the pig. In Current Concepts of Digestion and Absorption in Pigs, NIRD-HRI Technical Bulletin no. 3, pp. 136-150 [A. G. Low and I. G. Partridge, editors]. Reading: National Institute for Research in Dairying.

Cortot, A., Phillips, S. F. \& Malagelada, J. R. (1979). Gastric emptying of lipids after ingestion of an homogenized meal. Gastroenterology 76, 939-944.

Cortot, A., Phillips, S. F. \& Malagelada, J. R. (1982). Parallel gastric emptying of nonhydrolyzable fat and water after a solid -liquid meal in humans. Gastroenterology 82, 877-881.

Cranwell, P. D. (1985). The development of acid and pepsin (EC 3.4.23.1) secretory capacity in the pig; the effects of age and weaning. 1. Studies in anaesthetized pigs. British Journal of Nutrition 54, 305-320.

Cranwell, P. D. (1986). Development of the stomach and gastric secretions in the baby and the piglet. Proceedings of the XIII Congress of Nutrition, pp. 650-652 [T. G. Taylor and N. K. Jenkins, editors]. London: John Libbey.

Cranwell, P. D., Foltmann, B., Newport, M. J. \& Howarth, G. L. (1987). Basal and pentagastrin-induced gastric acid and milk-clotting enzyme secretion in pigs from birth to 4 weeks of age. Proceedings of the Nutrition Society 46, 25A.

Creutzfeldt, W., Ebert, R., Finke, U., Konturek, S. J., Kwiecień, N. \& Radecki, T. (1983). Inhibition of gastric secretion by fat and hypertonic glucose in the dog: role of gastric inhibitory peptide. Journal of Physiology 334, 91-101.

Cuber, J. C., Kaboré, C. \& Laplace, J. P. (1981) [Gastric emptying of ground barley and wheat compared in pigs.] Reproduction, Nutrition, Développement 21, 773.

Cuber, J. C., Laplace, J. P. \& Villiers, P. A. (1980). [Fistulation of the stomach and residual gastric contents after intake of a semi-purified diet based on maize in the pig.] Reproduction, Nutrition, Développement 20, $1161-1172$.

de Castro, J. M. (1981). The stomach energy content governs meal patterning in the rat. Physiology and Behavior 26, 795-798.

Decuypère, J. A., Bossuyt, R. \& Henderickx, H. K. (1978). Gastric secretion in suckling pigs and early-weaned pigs given a dry cow's-milk formula ad lib. British Journal of Nutrition 40, 91-102.

Decuypère, J. A., Knockaert, P. \& Henderickx, H. K. (1981). In virro and in vivo protein digestion in pigs fed diets containing soybean protein isolates with different physical properties. Journal of Animal Science 53, 1297-1308.

Ebihara, K., Masuhara, R. \& Kiriyama, S. (1981). Major determinants of plasma glucose-flattening activity of a water-soluble dictary fiber : effects of konjac mannan on gastric emptying and intraluminal glucose-diffusion. Nutrition Reports International 23, 11451156.

Edmunds, B. K., Buttery, P. J. \& Fisher, C. (1978). Protein turnover and whole body nitrogen metabolism in the growing pig. Proceedings of the Nutrition Society 37, 32A. 
Ehrlein, H. J. \& Pröve, J. (1982). Effect of viscosity of test meals on gastric emptying in dogs. Quarterly Journal of Experimental Physiology 67, 419425.

Elashoff, J. D., Reedy, T. J. \& Meyer, J. H. (1982). Analysis of gastric emptying data. Gastroenterology 83, $1306-1312$

Feldman, E. J., Isenberg. J. I. \& Grossman, M. I. (1981). Gastric acid and gastrin response to decaffeinated coffee and a peptone meal. Journal of the American Medical Association 246, 248-250.

Feldman, M., Walsh, J. H., Wong, H. C. \& Richardson, C. T. (1978). Role of gastrin heptadecapeptide in the acid secretory response to amino acids in man. Journal of Clinical Investigation 61, 308-313.

Fink, C. S., Hamosh, P. \& Hamosh, M. (1984). Fat digestion in the stomach: stability of lingual lipase in the gastric environment. Pediatric Research 18, 248--254.

Fisher, M. \& Hunt, J. N. (1977). Effects of hydrochlorides of amino acids in test meals on gastric emptying. Digestion 16, 1822.

Flemström, G. \& Garner, A. (1982). Gastroduodenal $\mathrm{HCO}_{3}$ transport: characteristics and proposed role in acidity regulation and mucosal protection. American Journal of Physiology 242, G183-193.

Foltmann, B., Jensen, A. L., Lonblad, P., Smidt, E. \& Axelsen, N. H. (1981). A developmental analysis of the production of chymosin and pepsin in pigs. Comparative Biochemistry and Physiology 68 B, 9-13.

Gilbert, A. J. \& Hersey, S. J. (1982). Exocytosis in isolated gastric glands induced by secretagogues and hyperosmolarity. Cell and Tissue Research 227, 535-542.

Giusi-Perier, A., Fiszlewicz, M. \& Rérat, A. (1989). Influence of diet composition on intestinal volatile fatty acid and nutrient absorption in unanesthetized pigs. Journal of Animal Science 67, $386-402$.

Gridin, N. Ja. (1956). [Dynamics of gastric secretion in the pig with different kinds of feed.] Fiziologicheskii Zhurnal SSSR Sechenova 42, 773-778.

Grötzinger, U., Bergegárdh, S. \& Olbe, L. (1977). Effect of atropine and proximal gastric vagotomy on the acid response to fundic distension in man. Gut 18, 303-310.

Hamosh, M., Sivasubramanian, K. N., Salzmann, C. \& Hamosh, P. (1978). Fat digestion in the stomach of premature infants. 1. Characteristics of lipase activity. Journal of Pediatrics 93, 674-679.

Henschel, M.J. (1973). Comparison of the development of proteolytic activity in the abomasum of the preruminant calf with that in the stomach of the young rabbit and guinea-pig. British Journal of Nutrition 30 , 285-296.

Hersey, S. J., Norris, S. H. \& Gilbert, A. J. (1984). Cellular control of pepsinogen secretion. Annual Review of Physiology 46, 393-402.

Hinder, R. A., Horn, B. K. P. \& Bremner, C. G. (1976). The volumetric measurement of gastric emptying and gastric secretion by radioisotope method. American Journal of Digestive Diseases 21, 940945.

Hinder, R. A. \& Kelly, K. A. (1977). Canine gastric emptying of solids and liquids. American Journal of Physiology 233, E335 E340.

Holgate, A. M. \& Read, N. W. (1985). Effect of ileal infusion of Intralipid on gastrointestinal transit, ileal flow rate, and carbohydrate absorption in humans after ingestion of a liquid meal. Gastroenterology 88, $1005-1011$.

Holt, S., Heading, R. C., Carter, D. C., Prescott, L. F. \& Tothill, P. (1979). Effect of gel fibre on gastric emptying and absorption of glucose and paracetamol. Lancet i, 636.639.

Holt, S., Reid, J., Taylor, T. V., Tothill, P. \& Heading, R. C. (1982). Gastric emptying of solids in man. Gut 23, 292296.

Hopkins, A. (1966). The pattern of gastric emptying: a new view of old results. Journal of Physiology 182, 144 - 149.

Hunt, J. N. (1954). Viscosity of a test meal: its influence on gastric emptying and secretion. Lancet i, 17-18.

Hunt, J. N. (1980). A possible relation between the regulation of gastric emptying and food intake. American Journal of Physiology 239, G1-G4.

Hunt, J. N. (1983). Mechanisms and disorders of gastric emptying. Annual Review of Medicine 34, 219-230.

Hunt, J. N. \& Knox, M. T. (1968a). Regulation of gastric emptying. In Handbook of Physiology, section 6, The Alimentary Canal, Vol. 4, Motility, pp. 1917-1935 [C.F.Code, editor]. Washington, DC: American Physiological Society.

Hunt, J. N. \& Knox, M. T. (1968b). A relation between the chain length of fatty acids and the slowing of gastric emptying. Journal of Physiology 194, 327-336.

Hunt, J. N. \& Knox, M. T. (1972). The slowing of gastric emptying by four strong acids and three weak acids. Journal of Physiology 222, 187-208.

Hunt, J. N. \& Macdonald, I. (1952). The relation between the volume of a test meal and the gastric secretory response. Journal of Physiology 117, 289-302.

Hunt, J. N. \& Macdonald, I. (1954). The influence of volume on gastric emptying. Journal of Physiology 126, $459-474$

Hunt, J. N. \& McHugh, P. R. (1982). Does calcium mediate the slowing of gastric emptying in primates? American Journal of Physiology 243, G200-203.

Hunt, J. N., Smith, J. L. \& Jiang, C. L. (1985). Effect of meal volume and energy density on the gastric emptying of carbohydrates. Gastroenterology 89, 1326-1330.

Hunt, J. N. \& Spurrell, W. R. (1951). The pattern of emptying of the human stomach. Journal of Physiology 113, $157-168$ 
Hunt, J. N. \& Stubbs, D. F. (1975). The volume and energy content of meals as determinants of gastric emptying. Journal of Physiology 245, 209225.

Isenberg, J. I., Ippoliti, A. F. \& Maxwell, V. L. (1977). Perfusion of the proximal small intestine with peptone stimulates gastric acid sectetion in man. Gastroenterology 73, 746-752

Isenberg, J. I. \& Maxwell, V. (1978). Intravenous infusion of amino acids stimulates gastric acid secretion in man. New England Journal of Medicine 298, 27. 29.

Kalogeris, T. J., Reidelberger, R. D. \& Mendel, V. E. (1983). Effect of nutrient density and composition of liquid meals on gastric emptying in feeding rats. American Journal of Physiology 244, R865-R871.

Kaufmann, W. (1984a). [Influence of different technological treatments of milk on digestion in the stomach. I. Nutritional importance of milk and milk constituents in the stomach.] Milchwissenschaft 39, 259-261.

Kaufmann, W. $(1984 b)$. [Influence of different technological treatments of milk on digestion in the stomach. VI. Estimation of amino acid and urea concentrations in the blood; conclusions regarding the nutritional evaluation.] Milchwissenschaft 39, 281284.

Keegan, D. J. \& Devilliers, P. (1980). Changes in blood glucose concentration after the introduction of different solutions into the tied-off stomach of the rat. South African Journal of Science 76, 570.

Keinke, O. \& Ehrlein, H. J. (1983). Effect of oleic acid on canine gastroduodenal motility, pyloric diameter and gastric emptying. Quarterly Journal of Experimental Physiology 68, 675-686.

Kelly, K. A. (1980). Gastric emptying of liquids and solids: roles of proximal and distal stomach. American Journal of Physiology 239, G71 -G76.

Konturek, S. J., Biernat J. \& Oleksy, J. (1974). Serum gastrin and gastric acid responses to meals at various pH levels in man. Gut 15, 526-530.

Konturek, S. J., Bilski, J., Tasler, J. \& Laskiewicz, J. (1985). Gut hormones in stimulation of gastroduodenal alkaline secretion in conscious dogs. American Journal of Physiology 248, G687-G691.

Konturek, S. J. \& Johnson, L. R. (1971). Evidence for an enterogastric reflex for the inhibition of acid secretion. Gastroenterology 61, 667-674.

Konturek, S. J. Mikos, E., Pawlik, W. \& Walus, K. (1979). Direct inhibition of gastric secretion and mucosal blood flow by arachidonic acid. Journal of Physiology 286, 15-28.

Kotrba, C. \& Code, C. F. (1969). Gastric acid secretory responses to some purified foods and to addition of sucrose or olive oil. American Journal of Digestive Diseases 14, 1 8.

Kvasnitskii, A. V. (1951). [Problems of Digestive Physiology in Pigs.] Moscow: Sel'Khozgiz.

Laplace, J. P. (1980). Stomach and small intestine motility in the pig: electromyography in nutritional studies. In Current Concepts of Digestion and Absorption in Pigs, NIRD-HRI Technical Bulletin No. 3, pp. 24-51 [A. G. Low and I. G. Partridge, editors]. Reading: National Institute for Research in Dairying.

Laplace, J. P., Kaboré, C. \& Cuber, J. C. (1985b). [Gastric emptying of ground maize in the pig.] Annales de Zootechnie 34, 283-290.

Laplace, J. P., Pons, O., Cuber, J. C. \& Kaboré, C. (1984). [Gastric emptying and amino acid composition of the dietary proteins in the pig.] Annales de Zootechnie 33, 59-72.

Laplace, J. P., Pons, O., Cuber, J. C. \& Kaboré, C. (1985a). [Gastric emptying of barley and wheat in the pig.] Annales de Zootechnie 34, 265-282.

Laplace, J. P., Pons, O. \& Simon, P. (1983). [Revision of the effects of dietary sources of starch and protein on gastric emptying in the pig.] Annales de Zootechnie 32, 507-524.

Lawrence, T. L. J. (1970). Some effects of including differently processed barley in the diet of the growing pig. 2 . In vivo gastric pH changes. Animal Production 12, 151-163.

Lawrence, T. L. J. (1972). The effect of certain dietary factors on in vivo $\mathrm{pH}$ changes and pepsin activity in the stomach of the growing pig. British Veterinary Journal 128, 402-411.

Leib, M. S., Wingfield, W. E., Twedt, D. C. \& Williams, A. R. (1986). Gastric emptying of liquids in the dog: effect of volume. American Journal of Veterinary Research 47, 1019-1021.

Lenz, H. J., Ferrari-Taylor, J. \& Isenberg, J. I. (1983). Wine and five percent ethanol are potent stimulants of gastric acid secretion in humans. Gastroenterology 85, 1082-1087.

Liao, T. H., Hamosh, P. \& Hamosh, M. (1984). Fat digestion by lingual lipase: mechanisms of lipolysis in the stomach and upper small intestine. Pediatric Research 18, 402-409.

Low, A. G., Pittman, R. J. \& Elliott, R. J. (1985). Gastric emptying of barley-soya-bean diets in the pig: effects of feeding level, supplementary maize oil, sucrose or cellulose, and water intake. British Journal of Nutrition $\mathbf{5 4}$, $437-447$

Low, A. G. \& Rainbird, A. L. (1986). Lack of evidence for amino acid and glucose absorption in the stomach of pigs. Archiv für Tierernährung 36, 327.

McArthur, K., Hogan, D. \& Isenberg, J. I. (1982). Relative stimulatory effects of commonly-ingested beverages on gastric acid secretion in humans. Gastroenterology 83, 199-203.

McCann, M. J. \& Stricker, E. M. (1986). Gastric emptying of glucose loads in rats: effects of insulin-induced hypoglycemia. American Journal of Physiology 251, R609-R613.

MacGregor, I. L., Deveney, C., Way, L. W. \& Meyer, J. H. (1976). The effect of acute hyperglycemia on mealstimulated gastric, biliary, and pancreatic secretion, and serum gastrin. Gastroenterology 70, 197-202. 
McHugh, P. R. \& Moran, T. H. (1979). Calorics and gastric emptying: a regulatory capacity with implications for feeding. American Journal of Physiology 236, R254-R260.

McHugh, P. R., Moran, T. H. \& Wirth, J. B. (1982). Postpyloric regulation of gastric emptying in rhesus monkeys. American Journal of Physiology 243, R408 -R415.

Malagelada, J. R., Go, V. L. W. \& Summerskill, W. H. J. (1979). Different gastric, pancreatic, and biliary responses to solid-liquid or homogenized meals. Digestive Diseases and Sciences 24, 101-110.

Mangel, A. W. \& Koegel, A. (1984). Effects of peptides on gastric emptying. American Journal of Physiology 246, G342-G345.

Mecroff, J. C., Go, V. L. W. \& Phillips, S. F. (1975). Control of gastric emptying by osmolality of duodenal contents in man. Gastroenterology 68, 11441151.

Meisel, H. \& Hagemeister, H. (1984). [Influence of different technological treatments of milk on digestion in the stomach. II. Gastric passage of different milk constituents.] Milchwissenschaft 39, 262-266.

Meyer, J. H., Mayer, E. A., Jehn, D., Gu, Y., Fink, A. S. \& Fried, M. (1986). Gastric processing and emptying of fat. Gastroenterology 90, 1176-1187.

Meyer, J. H., Thomson, J. B., Cohen, M. B., Shadchehr, A. \& Mandiola, S. A. (1979). Sieving of solid food by the canine stomach and sieving after gastric surgery. Gastroenterology 76, 804-813.

Minami, H. \& McCallum, R. W. (1984). The physiology and pathophysiology of gastric emptying in humans. Gastroenterology 86, 1592-1610.

Moran, T. H. \& McHugh, P. R. (1981). Distinctions among three sugars in their effects on gastric emptying and satiety. American Journal of Physiology 241, R25- R30.

Morgan, K. G., Schmalz, P. F., Go, V. L. W. \& Szurszewski, J. H. (1978). Effects of pentagastrin, $G_{17}$, and $G_{34}$ on the electrical and mechanical activities of canine antral smooth muscle. Gastroenterology 75, 405-412.

Morgan, L. M., Tredger, J. A., Madden, A., Kwasowski, P. \& Marks, V. (1985). The effect of guar gum on carbohydrate-, fat- and protein-stimulated gut hormone secretion: modification of postprandial gastric inhibitory polypeptide and gastrin responses. British Journal of Nutrition 53, 467475.

Myers, B. M., Smith, J. L. \& Graham, D. Y. (1987). Effect of red pepper and black pepper on the stomach American Journal of Gastroenterology 82, 211-214.

Newport, M. J. (1979). Artificial rearing of pigs. 9. Effect of replacement of dried skim-milk by fish-protein concentrate on performance and digestion of protein. British Journal of Nutrition 41, 103-110.

Newport, M. J. (1980). Artificial rearing of pigs. 11. Effect of replacement of dried skim-milk by isolated soyabean protein on the performance of the pigs and digestion of protein. British Journal of Nutrition 44, $171-178$.

Newport, M. J. \& Henschel, M. J. (1984). Evaluation of the neonatal pig as a model for infant nutrition: effects of different proportions of casein and whey protein in milk on nitrogen metabolism and composition of digesta in the stomach. Pediatric Research 18, 658-662.

Newport, M. J. \& Keal, H. D. (1980). Artificial rearing of pigs. 10. Effect of replacing dried skim-milk by a singlecell protein (Pruteen) on performance and digestion of protein. British Journal of Nutrition 44, $161-170$.

Newport, M. J. \& Keal, H. D. (1982). Artificial rearing of pigs. 12. Effect of replacement of dried skim-milk by either a soya-protein isolate or concentrate on the performance of the pigs and digestion of protein. British Journal of Nutrition 48, 89-96.

Nicholl, C. G., Polak, J. M. \& Bloom, S. R. (1985). The hormonal regulation of food intake, digestion, and absorption. Annual Review of Nutrition 5, 213-239.

Notivol, R., Carrio, I., Cano, L., Estorch, M. \& Vilardell, F. (1984). Gastric emptying of solid and liquid meals in healthy young subjects. Scandinavian Journal of Gastroenterology 19, $1107 \cdot 1113$.

Pappas. T. N., Debas, H. T., Chang, A. M. \& Taylor, I. L. (1986). Peptide YY release by fatty acids is sufficient to inhibit gastric emptying in dogs. Gastroenterology 91, 1386-1389.

Petersen, B., Christiansen, J. \& Holst, J. J. (1985). A glucose-dependent mechanism in jejunum inhibits gastric acid secretion: a response mediated through enteroglucagon? Scandinavian Journal of Gastroenterology 20,193 -197.

Petersen, W. L., Barnett, C. \& Walsh, J. H. (1986). Effect of intragastric infusions of ethanol and wine on serum gastrin concentration and gastric acid secretion. Gastroenterology 91, 1390-1395

Pfeil, R. (1984). [Influence of different technological treatments of milk on the digestion in the stomach. III. Proteolysis in the stomach.] Milchwissenschaft 39, 267-270.

Potkins, Z. V. \& Lawrence, T. L. J. (1984). Studies on the effects of composition and physical form of the diet on gastric abnormalities and nutrient utilization in the growing pig. Animal Production 38, 534.

Pröve, J. \& Ehrlein, H. J. (1982). Motor function of gastric antrum and pylorus for evacuation of low and high viscosity meals in dogs. Gut 23, 150-156.

Rainbird, A. L. (1986). Effect of guar gum on gastric emptying of test meals of varying energy content in growing pigs. British Journal of Nutrition 55, 99-109.

Rainbird, A. L. \& Low, A. G. (1986a). Effect of guar gum on gastric emptying in growing pigs. British Journal of Nutrition 55, 87-98.

Rainbird, A. L. \& Low, A. G. (1986 b). Effect of various types of dietary fibre on gastric emptying in growing pigs. British Journal of Nutrition 55, 111-121.

Ratcliffe, B. (1985). The influence of the gut microflora on the digestive processes. In Digestive Physiology in the Pig, National Institute of Animal Science Publication no. 580, pp. 245-267 [A. Just, H. Jørgensen and J. A. Fernandez, editors]. Copenhagen: National Institute of Animal Science. 
Ray, T. K., Mansell, K. M., Knight, L. C., Malmud, L. S., Owen, O. E. \& Boden, G. (1983). Long-term effects of dietary fiber on glucose tolerance and gastric emptying in noninsulin-dependent diabetic patients. American Journal of Clinical Nutrition 37, 376-381.

Reed, J. H. \& Kidder, D. E. (1972). The effect of glucose, galactose and sorbitol on gastric emptying in the young pig. Quarterly Journal of Experimental Physiology 57, 30-36.

Rees, W. D. W., Botham, D. \& Turnberg, L. A. (1982). A demonstration of bicarbonate production by the normal human stomach in vivo. Digestive Diseases and Sciences 27, 961-966.

Reimann, E. M., Maxwell, C. V., Grummer, R. H., Kowalczyk, T., Benevenga, N. J. \& Hoekstra, W. G. (1967). Differential effect of dietary particle size on the contents of various regions of the swine stomach. Journal of Animal Science 26, 1498.

Richardson, C. T., Walsh, J. H., Hicks, M. I. \& Fordtran, J. S. (1976). Studies on the mechanisms of foodstimulated gastric acid secretion in normal human subjects. Journal of Clinical Investigation 58, 623-631.

Roy, J. H. B. (1980). The Calf, 4th ed. London: Butterworths.

Russell, J. \& Bass, P. (1985). Canine gastric emptying of fiber meals : influence of meal viscosity and antroduodenal motility. American Journal of Physiology 249, G662 G667.

Saint-Hilaire, S., Lavers, M. K., Kennedy, J. \& Code, C. F. (1960). Gastric acid secretory value of different foods. Gastroenterology 39, 1-11.

Sandhu, K. S., El Samahi, M. M., Mena, I., Dooley, C. P. \& Valenzuela, J. E. (1987). Effect of pectin on gastric emptying and gastroduodenal motility in normal subjects. Gastroenterology 92, 486-492.

Sasaki, H., Nagulesparan, M., Dubois, A., Vasquez, B., Straus, E., Sievers, M. L. \& Unger, R. H. (1983). Inhibitory effect of intragastric glucose on gastric acid secretion and gastric emptying of liquids in man: role of endogenous somatostatin, gastrin, and insulin. Digestive Diseases and Sciences 28, 502-506.

Schoon. I. M. (1988). The effects of antral distension on gastric acid secretion and on the release of gastrointestinal hormones in man. Acta Physiologica Scandinavica 482, Suppl. 33 pp.

Schwartz, S. E., Levine, R. A., Singh, A., Scheidecker, J. R. \& Track, N. S. (1982). Sustained pectin ingestion delays gastric emptying. Gastroenterology 83, 812-817.

Simon, O. (1989). Metabolism of proteins and amino acids. In Protein Metabolism in Farm Animals, pp. 273-366 [H. D. Bock, B. O. Eggum, A. G. Low, O. Simon and T. Zebrowska, editors]. Oxford: Oxford University Press.

Smith, J. L., Jiang, C. L. \& Hunt, J. N. (1984). Intrinsic emptying pattern of the human stomach. American Journal of Physiology 246, R959 R962.

Soares, E. C., Zaterka, S. \& Walsh, J. H. (1977). Acid secretion and serum gastrin at graded intragastric pressures in man. Gastroenterology 72, 676-679.

Stephens, J. R., Woolson, R. F. \& Cooke, A. R. (1975). Effects of essential and nonessential amino acids on gastric emptying in the dog. Gastroenterology 69, 920-927.

Storozhuk, P. G. (1968). [Effect of protein products on gastric secretion in dogs.] Voprosy Pitaniya 27 (5), $50-55$

Strunz, U. T., Walsh, J. H. \& Grossman, M. I. (1978). Stimulation of gastrin release in dogs by individual amino acids. Proceedings of the Society for Experimental Biology and Medicine 157, 440-441.

Stubbs, D. F. (1977). Models of gastric emplying. Gut 18, 202-207.

Tadesse, K. (1986). The effect of dietary fibre isolates on gastric secretion, acidity and emptying. British Journal of Nutrition 55, 507-513.

Taylor, I. L.. Byrne, W. J., Christie, D. L., Ament, M. E. \& Walsh, J. H. (1982). Effect of individual L-amino acids on gastric acid secretion and serum gastrin and pancreatic polypeptide release in humans. Gastroenterology 83, 273-278.

Thomas, P. A., Schang, J. C., Kelly, K. A. \& Go, V. L. W. (1980). Can endogenous gastrin inhibit canine interdigestive gastric motility? Gastroenterology 78, 716-721.

Timmen, H. \& Precht, D. (1984). [Influence of different technological treatments of milk on digestion in the stomach. V. Lipolysis in the stomach.] Milchwissenschaft 39, 276-280.

Torsdottir, I., Alpsten, M., Andersson, D., Brummer, R. J. M. \& Andersson, H. (1984). Effect of different starchy foods in composite meals on gastric emptying rate and glucose metabolism. 1. Comparisons between potatoes, rice and whitc beans. Human Nutrition: Clinical Nutrition 38C, 329-338.

Trout, D. L. \& Bernstein, P. A. (1986). Intake and gastric emptying of mono- versus disaccharides by rats. Journal of Nutrition 116, 1682-1693.

Trout, D. L., Putney, J. D. \& Conway, E. S. (1978). Relative rates of gastric emptying of glucose vs. fat in rats fed nonliquid meals. American Journal of Physiology 234, E660 E666.

Tsai, A. C. \& Peng, B. (1981). Effects of locust bean gum on glucose tolerance, sugar digestion and gastric motility in rats. Journal of Nutrition 111, 2152-2156.

Walsh, J. H. (1988). Peptides as regulators of gastric acid secretion. Annual Review of Physiology 50, $41-63$.

Walsh, J. H., Richardson, C. T. \& Fordtran, J. S. (1975). pH dependence of acid secretion and gastrin release in normal and ulcer patients. Journal of Clinical Investigation 55, $462-469$.

Ward, A. S., Wilkins, R. A., Cockel, R. \& Windsor, C. W. O. (1969). Duodenal inhibition of gastric secretion by osmotic agents in normal subjects and patients with duodenal ulcer. Gut 10, 1020-1028.

Weiner, K., Graham, L. S., Reedy, T., Elashoff, J. \& Meyer, J. H. (1981). Simultaneous gastric emptying of two solid foods. Gastroenterology 81, 257266. 
Williams, V. J., Roy, J. H. B. \& Gillies, C. M. (1976). Milk substitute diet composition and abomasal secretion in the calf. British Journal of Nutrition 36, 317335 .

Wilmshurst, P. \& Crawley, J. C. W. (1980). The measurement of gastric transit time in obese subjects using ${ }^{24} \mathrm{Na}$ and the effects of energy content and guar gum on gastric emptying and satiety. British Journal of Nutrition 44, $1-6$.

Zebrowska, T. (1968). The course of digestion of different food proteins in the rat. Fractionation of the nitrogen in intestinal contents. British Journal of Nutrition 22, 483-491.

Zebrowska, T., Low, A. G. \& Zebrowska, H. (1983). Studies on gastric digestion of protein and carbohydrate, gastric secretion and exocrine pancreatic secretion in the growing pig. British Journal of Nutrition $49,401-410$. 